\title{
REGIONAL FEATURES OF TRANSPLANT ACTIVITY IN EUROPE AND EASTERN MEDITERRANEAN/AFRICA DEPENDING ON MACROECONOMIC INDICATORS
}

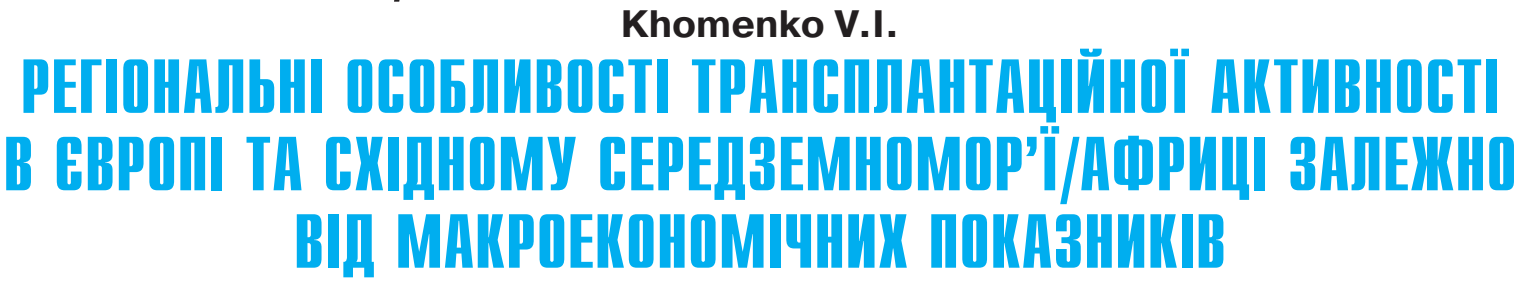

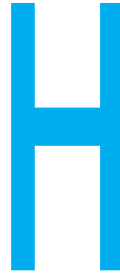

XОМЕНКО В.I.

Київський центр

трансплантації

кісткового мозку

УДК: 616.155.392089.843:611.

018.46]:330.34(477)

$+615.361$

Ключові слова: трансплантація

гемопоетичних

стволових клітин,

рівні

трансплантаційної активності,

валовий

національний

дохід на душу населення,

витрати системи

охорони здоров'я

на душу населення ині трансплантація гемопоетичних стовбурових клітин (ТГСК) стала пріоритетною терапевтичною стратегією у лікуванні багатьох гематологічних, онкологічних та непухлинних захворювань. Цей метод лікування являє собою комплекс надзвичайно ресурсномістких і високовартісних процедур, для застосування яких необхідні спеціальна інфраструктура та досвідчена мультидисциплінарна команда фахівців у галузі гематології, онкології, трансплантології, інтенсивної терапії, імуногенетики та інших. Дослідження Khera і співавторів показують, що госпітальні видатки на ТГСК у країнах світу з низькими або високими доходами можуть коливатись у значному діапазоні: від 36 до 88 тис. дол. США для однієї аутологічної трансплантації та від 200 тис. дол. США і вище для алогенної від неродинного донора з використанням мієлоаблятивних режимів кондиціонування [1].

Незважаючи на високу вартість ТГСК досить швидко розвивається у світі. Якщо 2006 року у світі було виконано понад 50 тис. ТГСК, то 2012 р. їхня кількість перевищила 68 тис. на рік. Питома вага алогенних трансплантацій збільшилася до 47\%, а аутологічні становили 53\%. Зростанню трансплантаційної актив- ності сприяв розвиток інфраструктури, пов'язаної з ТГСК. У 2012 році у 77 країнах світу функціонувало понад 1560 трансплантаційних команд. Збільшення кількості донорів-волонтерів у реєстрах світу (понад 22 млн.) та зразків пуповинної крови (до 650 тис.) сприяв збільшенню кількості алогенних ТГСК від неродинних донорів [2, 3].

Не має сумніву, що ТГСК $є$ одним 3 найбільш інноваційних, високотехнологічних та високовартісних методів лікування, який може створити значне економічне навантаження на будь-яку систему охорони здоров'я. Наприклад, у США ТГСК входить до переліку з десяти найбільш високовартісних методів лікування. Госпітальні видатки на ТГСК у період з 2004 по 2007 роки зросли майже на 85\%. Це відбувалося завдяки збільшенню кількості трансплантацій (59\%) та підвищенню середньої вартості перебування у стаціонарі (26\%). Загальний обсяг витрат на ТГСК у США досяг у 2007 році майже 1,3 млрд. дол. [4]

Висока вартість ТГСК робить її недоступною для пересічного пацієнта. Тому наявність достатніх для її забезпечення ресурсів, належна державна підтримка охорони здоров'я є ключовими факторами, які
РЕГИОНАЛЬНЫЕ ОСОБЕННОСТИ

ТРАНСПЛАНТАЦИОННОЙ АКТИВНОСТИ

В ЄВРОПЕ И ВОСТОЧНОМ СРЕДИЗЕМНОМОРЬЕ ААФРИКЕ В ЗАВИСИМОСТИ

ОТ МАКРОЭКОНОМИЧЕСКИХ ПОКАЗАТЕЛЕЙ

Хоменко В.И. (Киев)

Количество трансплантаций гемопоэтических стволовых клеток (ТГСК) увеличивается во всем мире. Однако увеличение использования этого дорогостоящего метода лечения имеет экономический аспект. Уровни трансплантационной активности (количество ТГСК на 10 миллионов населения) значительно отличаются между странами со средними и высокими доходами в Европе и Восточном Средиземноморье/Африке. В странах с низкими доходами не было выполнено ни одной ТГСК. Уровни трансплантационной активности (общие, для аллогенных и аутологичных ТГСК) в этих странах и регионах ассоциированы с валовым национальным доходом на душу населения, затратами здравоохранения (общими и государственными) на душу населе- ния, количеством трансплантационных команд на 1 миллион населения. Трансплантационная активность была сконцентрирована преимущественно в странах Западной Европы с высокими доходами в сравнении со странами

Центральной и Восточной Европы, Содружества Независимых Государств и Восточного

Средиземноморья/Африки. Описанные отличия трансплантационной активности отражают различия в ресурсах между странами с низкими и высокими доходами, а также значительные региональные отличия. Эти данные обеспечивают базис для планирования в области здравоохранения и разработки нормативных актов в Украине для развития ТГСК как экономически эффективного метода лечения.

\section{Ключевые слова: трансплантация} гемопоэтических стволовых клеток, уровни трансплантационной активности, валовый национальный доход на душу населения, затраты здравоохранения на душу населения.

() Хоменко В.І. СТАТТЯ, 2017. 
REGIONAL FEATURES OF TRANSPLANT ACTIVITY IN EUROPE AND EASTERN MEDITERRANEAN/AFRICA DEPENDING ON MACROECONOMIC INDICATORS Khomenko V.I.

Kyiv City Bone Marrow Transplantation Center, Kyiv, Ukraine

Number of hemopoietic stem cells transplantation (HSCT) increases worldwide. However, the increasing use of this expensive treatment modality has an economic aspect. Transplant activity rates (number of HSCT per 10 millions inhabitants) differ significantly between middle and high income countries in Europe and Eastern Mediterranean/Africa. Any HSCT was not performed in low income countries. In these countries and regions the transplant rates (total, for allogenic and autologous HSCT) are associated with a gross national income per capita, health care expenditures (total and governmental) per capita, number of transplant teams per 1 million inhabitants. Transplant activity was concentrated preferentially in high income countries of Western Europe in comparison with the countries of Central and Eastern Europe, Commonwealth of Independent States, Eastern Mediterranean/Africa. The described differences of transplant activity present differences in the resources between low and high income countries and the significant regional differences as well. These data provide a basis for health care planning and development of normative acts for the development of HSCT as a cost effective treatment modality in Ukraine.

Keywords: hemopoietic stem cells transplantation, transplant rates, cross national income per capita, health care expenditures per capita. пов'язані з трансплантаційною активністю. Встановлено зв'язок трансплантаційної активності 3 рівнями економічного розвитку країн та їхніми видатками на охорону здоров'я. Ці фактори вважаються ключовими причинами диспропорційного розвитку ТГСК у світі та Європі [2, 5].

Країни Європи суттєво відрізняються за рівнями економічного розвитку. Україна значно відстає від країн Європи як за загальними рівнями трансплантаційної активності (РТА), так і у частині впровадження окремих видів ТГСК. Нині в Україні не створено умов для виконання алогенних ТГСК від гістоідентичних неродинних донорів. Відставання РТА від провідних країн Європи зумовлене низкою факторів економічного, інфраструктурного та кадрового характеру. Серед них відсутність належного фінансування $є$ одним з ключових, бо впливає на формування інфраструктури та підготовку спеціалістів міжнародного рівня. В Україні не проводилися дослідження щодо того, яким чином ці відмінності можуть бути асоційовані 3 трансплантаційною активністю у певній країні або регіоні.

Мета дослідження - провести аналіз стану ТГСК у країнах-членах Європейської групи з трансплантації крови та кісткового мозку (European Group for Blood and Marrow Transplantation - EBMT) залежно від макроекономічних індикаторів.

Матеріали і методи. Ocновним завданням було дати загальну характеристику стану ТГСК та інфраструктури, пов'язаної з нею, у країнах-чле- нах ЕВМТ у комплексі з макроекономічними індикаторами: валовим національним доходом на душу населення (ВНД/дн), загальними і державними видатками охорони здоров'я на душу населення (ЗВОЗ/дн і ДВОЗ/дн). Визначити зв'язок РТА (кількість ТГСК/10 млн. населення) у цих країнах $з$ щільністю трансплантаційних команд (кількість центрів ТГСК/1 млн. населення) та макроекономічними індикаторами (ВНД/дн, ЗВОЗ /дн, ДВОЗ/дн), розрахованими у доларах США та за паритетом купівельної спроможності за курсом міжнародного долара (ПКС), а також ЗВОЗ у \% від ВВП. Дослідити регіональні особливості трансплантаційної активності, стану інфраструктури, пов'язаної з ТГСК, між регіонами Європи та Східного Середземномор'я/Африки залежно від рівнів економічного розвитку країн-членів ЕВМТ.

у дослідженні використано опубліковані дані щодо кількості ТГСК та числа трансплантаційних команд у 45 країнахчленах EВMT за 2010 рік [6]. До ЕВМТ входили трансплантаційні команди 3 двох континентальних регіонів Всесвітньої організації охорони здоров'я (ВОО3): 38 країн Європи (Західна Європа (ЗЄ): Австрія, Бельгія, Данія, Фінляндія, Франція, Німеччина, Ісландія, Ірландія, Італія, Ізраїль, Греція, Кіпр, Люксембург, Нідерланди, Норвегія, Португалія, Туреччина, Велика Британія, Іспанія, Швеція, Швейцарія; Центральна і Східна Європа (ЦСЄ): Боснія-Герцоговина, Болгарія, Хорватія, Чехія, Естонія, Угорщина, Латвія, Литва, Македонія, Польща, Румунія, Сербія,
Словаччина, Словенія; Співдружність Незалежних Держав (СНД): Україна, Росія, Білорусь) та 7 країн Східного Середземномор'я/Африки (Алжир, Іран, Йорданія, Ліван, Саудівська Аравія, Туніс, Південна Африка).

Дані щодо чисельності населення у вищенаведених країнах, значення макроекономічних індикаторів (ВНД/дн, ЗВОЗ/дн, ДВОЗ/дн та ЗВОЗ у \% від ВВП) було отримано 3 офіційних сайтів Світового банку та ВООЗ $[7,8]$.

На основі отриманих даних нами розраховано РТА (загальні, а також для алогенних i аутологічних ТГСК) та показники щільності трансплантаційних команд (ЩТК) для кожної з країн-членів ЕВМТ. Статистичний аналіз отриманих даних, дослідження кореляційних зв'язків між РТА, показниками ЩТК і вищенаведеними макроекономічними індикаторами країн-членів ЕВМТ було проведено з використанням програми Statistica 10.

Результати та їх обговорення. Проаналізовано стан ТГСК у 45 країнах-членах ЕВМТ за 2010 рік. Цього року до ЕВМТ входило 656 трансплантаційних команд із 38 країн Європи і 7 країн Східного Середземномор'я/Африки. Загальна кількість населення у них становила 1019 млн. осіб. Чисельність населення в окремих країнах коливалась від 0,32 млн. в Ісландії до 142,8 млн. у Росії $(\mathrm{M} \pm \sigma=22,63 \pm 29,75)$. Кількість трансплантаційних команд у цих країнах коливалась від 1 в Ісландії, Кіпрі, Йорданії, Латвії, Люксембурзі, Македонії, Словенії, Тунісі до 108 у Німеччині $(\mathrm{M} \pm \sigma=14,58 \pm 25,82)$. ЩТК ста- 
новила від 0,04 в Ірані і Україні до 3,1 в Ісландії ( $\mathrm{M} \pm \sigma=0,80 \pm$ $0,62)$. отримали першу ТГСК (повторні трансплантації у цьому дослідженні не враховувалися). 3 них 12247 ТГСК були алогенними (40,9\%), а 17738 - аутологічними $(59,1 \%)$. Загальна кількість ТГСК коливалась від 9 у БосніїГерцоговині та Люксембурзі до 5345 у Німеччині $(\mathrm{M} \pm \sigma=666,93 \pm$ 1178,97). Кількість алогенних трансплантацій коливалась від 0 у Люксембурзі, Ісландії і Кіпрі до 2615 у Німеччині $(\mathrm{M} \pm \sigma=272,76$ $\pm 503,94)$, а аутологічних - від 7 у Боснії-Герцоговині до 2730 у Німеччині ( $\mathrm{M} \pm \sigma=394,18 \pm$ 686,07). Загальні РТА коливались від 11,34 в Україні до 845,10 в Ізраїлі ( $\mathrm{M} \pm \sigma=314,70 \pm$ 224,70). Для алогенних ТГСК РТА становили від 0 (Кіпр, Ісландія, Люксембург) до 433,1 в Ізраїлі ( \pm $\pm=116,88 \pm$ $104,63)$, а для аутологічних - від 10,68 в Україні до 422,70 в Італії $(\mathrm{M} \pm \sigma=197,44 \pm 132,22)$.

Аналіз макроекономічних індикаторів показав, що ВНД/дн у вищенаведених країнах коливався у дол. США від 2990 в Україні до 88430 у Норвегії (М $\pm \sigma=26420,44 \pm 22060,08)$, a за ПКС - від 7570 в Україні до 62890 у Люксембурзі ( $\mathrm{M} \pm \sigma=$ $27300,44 \pm 14057,66)$. ЗВО3 у відсотках від ВВП коливались від 4,0\% у Саудівській Аравії до $12,1 \%$ у Нідерландах ( $\mathrm{M} \pm \sigma=$ $8,42 \pm 1,93)$.

Подушові загальні і державні видатки охорони здоров'я країнчленів ЕВМТ у дол. США та за ПКС коливались у значному діапазоні: ЗВОЗ/дн у дол. США від 210 в Алжирі до 8164 у Норвегії $(\mathrm{M} \pm \sigma=2390,80 \pm 2291,76)$; ДВОЗ/дн у дол. США - від 131 в Україні до 6915 у норвегії (М $\pm \sigma=$

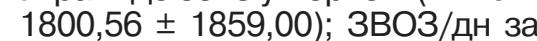
ПКС - від 591 в Алжирі до 6521 у Люксембурзі (M $\pm \sigma=2402,47 \pm$
2010 року 30012 пацієнтів

1567,35); ДВОЗ/дн за ПКС - від 339 в Україні до 5598 у Люксембурзі $(M \pm \sigma=1766,07 \pm$ 1320,54).

3 метою дослідження залежності трансплантаційної активності від стану інфраструктури, пов'язаної з ТГСК, та їх обох від рівнів економічного розвитку країн-членів ЕВМТ було проведено кореляційний аналіз. Досліджено кореляційні зв'язки РТА з показниками щТК та макроекономічними індикаторами (ВНД/дн, ЗВОЗ у \% від ВВП, ЗВОЗ/дн, ДВОЗ/Дн). Вірогідними вважали кореляції з імовірністю 95\% ( $\leq \leq 0,05)$.

Встановлено достовірні ( $\mathrm{p} \leq$ $0,05)$ прямі кореляційні зв'язки між ЩТК та загальним РТА $(r=0,76)$, а також РТА для алогенних $(r=0,52)$ і аутологічних ТГСК $(r=0,81)$.

Достовірні $(p \leq 0,05) \quad$ прямі кореляційні зв'язки встановлено між загальним РТА та ВНД/дн у дол. США і за ПКС ( $r=0,80$ і $r=0,73)$; ЗВОЗ у \% від ВВП ( $r=0,60)$; ЗВОЗ/дн у дол. США і за ПКС ( $r=0,79$ і $r=0,73)$; ДВОЗ/дн у дол. США і за ПКС $(r=0,82$ i $r=0,82)$.

Встановлено вірогідні $(p \leq 0,05)$ прямі кореляційні зв'язки між РТА для алогенних ТГСК та ВНД/дн у дол. США і за ПКС ( $r=0,63$ і $r=0,60)$; ЗВОЗ у \% від ВВП ( $r=0,53)$; ЗВОЗ/дн у дол. США і за ПКС (r=0,63 і $r=0,61)$; ДВОЗ/дн у дол. США і за ПКС $(r=0,64$ i $r=0,64)$.

Достовірні $(p \leq 0,05)$ прямі кореляційні зв'язки встановлено між РТА для аутологічних ТГСК та ВНД/дн у дол. США і за ПКС $(r=0,80$ i $r=0,71)$; ЗВОЗ у \%

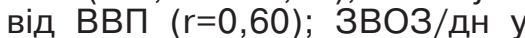
дол. США і за ПКС $(r=0,81$ $r=0,79) ;$ ДВОЗ/дн у дол. США і за ПКС ( $r=0,83$ і $r=0,82)$.

Встановлено вірогідні ( $\mathrm{p} \leq$ 0,05) прямі кореляції між показниками ЩТК та ВНД/дн у дол. США і за ПКС $(r=0,80$ i

Таблиця 1

Порівняльна таблиця показників ЩТК та РТА у країнах-членах ЕВМТ з високими і середніми доходами згідно з класифікацією Світового банку

\begin{tabular}{|c|c|c|c|c|c|c|}
\hline & \multicolumn{2}{|c|}{$\begin{array}{l}\text { Країни з високими } \\
\text { доходами }(\mathrm{n}=30) \\
\end{array}$} & \multicolumn{2}{|c|}{$\begin{array}{c}\text { Країни з середніми } \\
\text { доходами }(\mathrm{n}=15) \\
\end{array}$} & \multirow[t]{2}{*}{$\mathrm{t}$} & \multirow[t]{2}{*}{$P$} \\
\hline & $M$ & \pm & $M$ & \pm & & \\
\hline ЩТК & 1,08 & 0,58 & 0,26 & 0,18 & 5,316 & $<0,001$ \\
\hline PTA (загальний) & 430,93 & 183,19 & 82,23 & 48,17 & 7,210 & $<0,001$ \\
\hline $\begin{array}{l}\text { PТА (для ало- } \\
\text { генних ТГСК) }\end{array}$ & 161,48 & 101,05 & 27,68 & 21,57 & 5,043 & $<0,001$ \\
\hline $\begin{array}{l}\text { PТА (для ауто- } \\
\text { логічних ТГСК) }\end{array}$ & 268,88 & 100,80 & 54,56 & 32,97 & 7,984 & $<0,001$ \\
\hline
\end{tabular}

$r=0,70) ; 3 В О 3$ у \% від ВВП

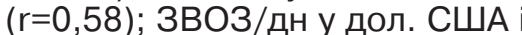
за ПКС ( $r=0,82$ i $r=0,80)$; ДВОЗ/дн у дол. США і за ПКС $(r=0,83$ i $r=0,80)$.

Таким чином, прямі кореляційні зв'язки між РТА (загальними, для алогенних і аутологічних ТГСК) і показниками ЩТК, а також макроекономічними індикаторами (ВНД/дн, ЗВОЗ/дн і ДВОЗ/дн, розрахованими у дол. США і за ПКС; ЗВОЗ у \% від ВВП) свідчать про те, що трансплантаційна активність та інфраструктура, пов'язана з нею, сконцентровані у країнах і регіонах, які мають вищий рівень економічного розвитку, більші загальні та державні видатки на охорону здоров'я.

Виходячи з вищенаведеного, було проведено порівняльний аналіз трансплантаційної активності між країнами-членами EBMT, розподіленими на групи за рівнем доходів згідно з класифікацією Світового банку. До категорії 3 високим рівнем доходів належали країни, в яких ВНД/дн дорівнював або перевищував 12276 дол. США, вище середнього - у межах від 3976 до 12275 дол. США, нижче середнього - від 1006 до 3975 дол. США, низьким - від 1005 дол. США і нижче [7].

До групи з високими доходами увійшло 30 країн-членів ЕВМТ (Австрія, Бельгія, Хорватія, Кіпр, Чехія, Данія, Естонія, Фінляндія, Франція, Німеччина, Греція, Угорщина, Ісландія, Ірландія, Ізраїль, Італія, Латвія, Литва, Люксембург, Нідерланди, Норвегія, Польща, Португалія, Словаччина, Словенія, Іспанія, Швеція, Швейцарія, Велика Британія, Саудівська Аравія), а до групи з середніми доходами - 15 (Білорусь, Боснія-Герцоговина, Болгарія, Алжир, Іран, Йорданія, Ліван, Румунія, Росія, Сербія, Македонія, Південна Африка, Туніс, Туреччина, Україна). Як бачимо, у країнах Європи та Східного Середземномор'я/Африки з низькими доходами не було виконано жодної трансплантації. Серед країн з середніми доходами Україна за величиною ВНД/дн належала до категорії з «доходом нижче середнього", а інші країни - 3 «доходом вище середнього».

При проведенні порівняльного аналізу між групами країн 3 високими і середніми дохода- 
ми до уваги брали показники, які відрізнялися один від одного $з$ імовірністю 95\% $(\mathrm{p} \leq 0,05)$.

Як видно з таблиці 1, середні значення показників ЩТК та РТА (загальні, а також для алогенних і аутологічних ТГСК) у країнах з високими доходами були значно вищими, ніж у країнах з середніми доходами. Наведені відмінності були достовірними.

Середні значення макроекономічних індикаторів (ВНД/дн, ЗВОЗ у \% від ВВП, ЗВОЗ/дн і ДВОЗ/дн) групи країн з високими доходами (табл. 2) значно перевищували аналогічні показники країн з середніми доходами. Ці відмінності мали достовірний характер.

Таким чином, розвиток ТГСК у країнах-членах ЕВМТ має диспропорційний характер: трансплантаційна активність та інфраструктура, пов'язана 3 ТГСК, сконцентровані у країнах з високими доходами. У країнах 3 низькими доходами не виконано жодної трансплантації. Країни з високими доходами мають можливість інвестувати більше коштів у розвиток інфраструктури (центри ТГСК, реєстри донорів, підготовку персоналу) та проведення оперативних втручань. Як наслідок, вони виконують значно більше аутологічних і алогенних ТГСК. Серед останніх трансплантації від неродинних донорів $€$ найбільш дорогими і складними з медичної та логістичної точки зору.

Враховуючи те, що країничлени ЕВМТ відрізняються за рівнями доходів, були досліджені регіональні особливості трансплантаційної активності між двома континентальними регіонами ВОО3 (Європа та Східне Середземномор'я/Африка), а також групами європейських країн: ЗЄ, пострадянські країни ЦСЄ та СНД, які перебувають на різних етапах реформування системи охорони здоров'я Семашка.

При проведенні порівняльного аналізу між континентальними регіонами Європи та Східного Середземномор'я/Африки встановлено, що ЩТК в Європі ( $\mathrm{M} \pm \sigma=0,92 \pm 0,60)$ була вірогідно вищою $(\mathrm{t}=3,278$; $\mathrm{p}<0,003)$, ніж у Східному Середземномор'ї/Африці (M \pm $\sigma=0,16 \pm 0,14)$. Загальний РТА в Європі (M $\pm \sigma=357,66 \pm$ $218,16)$ був достовірно вищим $(t=3,309 ; \quad p<0,002), \quad$ ніж $y$ Східному Середземномор'ї/Африці ( $\mathrm{M} \pm \sigma=81,46 \pm 40,06)$. PTA для алогенних (M $\pm \sigma=130,93 \pm$ $107,85)$ та аутологічних ТГСК в Європі ( $\mathrm{M} \pm \sigma=226,29 \pm$ $123,28)$ достовірно перевищували $(t=2,186 ; p<0,04$ i $t=3,930$; $\mathrm{p}<0,001$ відповідно) аналогічні показники у Східному Середземномор'ї/Африці (М $\pm \sigma=$ $40,63 \pm 22,77$ i 40,83 $\pm 24,60$ відповідно).

Порівняльний аналіз макроекономічних індикаторів (ВНД/дн, ЗВОЗ у \% від ВВП, ЗВОЗ/дн, ДВОЗ/Дн) виявив статистично значимі відмінності (табл. 3). Ці показники були значно вищими в Європі, ніж у Східному Середземномор'ї/Африці.

Таким чином, Європейський континентальний регіон ВООЗ, маючи більш високий рівень економічного розвитку порівняно зі Східним Середземномор'ям/Африкою, може значно більше витрачати на охорону здоров'я та розвиток інфраструктури, пов'язаної з ТГСК, як наслідок, має значно вищі PTA (загальні та для алогенних і аутологічних ТГСК).

Порівняльний аналіз між країнами З€ та пострадянськи-

\begin{tabular}{|c|c|c|c|c|c|c|}
\hline & \multicolumn{2}{|c|}{\begin{tabular}{|c|} 
Країни з високими \\
доходами $(\mathrm{n}=30)$
\end{tabular}} & \multicolumn{2}{|c|}{\begin{tabular}{|c|} 
Країни з середніми \\
доходами $(n=15)$
\end{tabular}} & & \multirow[t]{2}{*}{$P$} \\
\hline & $\mathrm{M}$ & $\pm \sigma$ & $M$ & $\pm \sigma$ & & \\
\hline ЗНД/дн, \$ & 36591,00 & 20371,77 & 6079,33 & 2197,38 & $5,751<$ & $<0,001$ \\
\hline ВНД/дн (ПКС) & 34306,33 & 11908,98 & |13288,67 & 3431,63 & $6,664<$ & $<0,001$ \\
\hline ЗВОЗ (\% від ВВГ & 8,96 & 1,87 & 7,34 & 1,63 & 2,856 & $<0,01$ \\
\hline ЗВОЗ/дн, \$ & 3366,43 & 236,72 & 439,53 & 156,62 & $5,033<$ & $<0,001$ \\
\hline ЗВОЗ/дн (ПК & 3135,33 & 1426,62 & 936,73 & 228,21 & $5,898<$ & $<0,001$ \\
\hline ДВОЗ/дн, \$ & 2569,67 & 75 & 262,33 & 6,91 & $4,813<$ & $<0,001$ \\
\hline ДВОЗ/дн (ПКС) & 2368,83 & 1227,90 & 560,53 & 147,36 & $5,651<<$ & $<0,001$ \\
\hline \multicolumn{7}{|c|}{$\begin{array}{c}\text { Порівняльна таблиця макроекономічних індикаторів } \\
\text { ВНД/дн, ЗВОЗ у \% від ВВП, ЗВОЗ/дн, ДВОЗ/дн країн } \\
\text { Європи та Східного Середземномор'я/Африки }\end{array}$} \\
\hline & \multicolumn{2}{|c|}{ Європа (n=38) } & \multicolumn{2}{|c|}{\begin{tabular}{|l|} 
Східне Середземно- \\
мор'я/Африка $(n=7)$ \\
\end{tabular}} & \multirow[t]{2}{*}{$\mathrm{t}$} & \multirow[t]{2}{*}{ P } \\
\hline & $\mathrm{M}$ & $\pm \sigma$ & $\mathrm{M}$ & $\pm \sigma$ & & \\
\hline ВНД/дн, \$ & 29960,26 & 22171,71 & 7204,29 & 5209,93 & 2,678 & $<0,02$ \\
\hline ВНД/дн (ПКС) & 29124,47 & 13773,99 & 17398,57 & 11990,85 & 2,106 & $<0,05$ \\
\hline ЗВОЗ (\% від ВВП) & 8,72 & 1,82 & 6,77 & 1,82 & 2,612 & $<0,02$ \\
\hline ЗВОЗ/дн, \$ & 2747,95 & 2323,41 & 452,00 & 183,18 & 2,589 & $<0,02$ \\
\hline ЗВОЗ/дн (ПКС) & 2661,50 & 1568,82 & 996,29 & 325,11 & 2,772 & $<0,01$ \\
\hline ДВОЗ/дн, \$ & 2088,37 & 1887,08 & 238,14 & 102,73 & 2,569 & $<0,02$ \\
\hline ДВОЗ/дн (ПКС) & 1992,58 & 1313,98 & 536,43 & 228,15 & 2,898 & $<0,01$ \\
\hline
\end{tabular}

ми країнами (ЦСЄ та СНД) виявив низку статистично значимих відмінностей. ЩТК у $3 €$ (M $\pm \sigma=1,24 \pm 0,58)$ була вірогідно вищою $(t=4,467 ; p<0,001)$, ніж y групі пострадянських країн (M $\pm \sigma=0,53 \pm 0,35)$. Загальний PTA y $3 E(M \pm \sigma=478,18 \pm$ $183,98)$ був достовірно вищим $(t=4,769 ; \quad p<0,001), \quad$ ніж $y$ пострадянських країнах ( $\mathrm{M} \pm \sigma$ $=208,79 \pm 158,57)$. РТА у $3 €$ для алогенних (M $\pm \sigma=183,21 \pm$ $108,83)$ та аутологічних ТГСК (М $\pm \sigma=294,16 \pm 96,11)$ достовірно перевищували ( $t=3,911$; $p<0,001$ i t $=4,743 ; p<0,001$ відповідно) аналогічні показники групи пострадянських країн (M $\pm \sigma=66,34 \pm 63,82$ і $142,45 \pm$ 100,42 відповідно)

Макроекономічні індикатори (ВНД/дн, ЗВОЗ у \% від ВВП, ЗВОЗ/дн, ДВОЗ/дн) у порівнюваних групах мали статистично значимі відмінності. Середні значення цих показників були достовірно вищими у $3 €$, ніж у групі пострадянських країн (табл. 4).

Таким чином, в Європейському континентальному регіоні ВООЗ трансплантаційна активність сконцентрована у країнах $3 €$, яка порівняно 3

Таблиця 2 
пострадянськими країнами (ЦСЄ та СНД) має вищі рівні економічного розвитку, більші загальні та державні видатки на охорону здоров'я, як наслідок - більш потужну інфраструктуру, пов'язану з ТГСК, та вищі РТА (загальні та для алогенних і аутологічних ТГСК).

Серед пострадянських країн Європи країни ЦСЄ розпочали реформування раніше, ніж країни СНД. Порівняльний аналіз між країнами $3 €$ та країнами ЦСЄ виявив низку статистично значимих відмінностей. щТК у $3 €(\mathrm{M} \pm \sigma=1,24 \pm 0,58)$ була вірогідно вищою ( $\mathrm{t}=3,685$; $\mathrm{p}<0,001)$, ніж у ЦСЄ ( $\mathrm{M} \pm \sigma=$ $0,61 \pm 0,32)$. Загальний РТА у $3 €(\mathrm{M} \pm \sigma=478,18 \pm 183,98)$ був достовірно вищим ( $t=3,956 ; p<0,001)$, ніж у країнax ЦСЄ (M $\pm \sigma=2242,30 \pm$ 154,04). РТА для алогенних (М $\pm \sigma=183,21 \pm 108,83)$ та аутологічних ТГСК у $3 €$ (M $\pm \sigma=$ $294,16 \pm 96,11)$ достовірно перевищували (t=3,253; $p<0,003$ i $t=3,910 ; p<0,001$ відповідно) аналогічні показники у ЦСЄ (M $\pm \sigma=77,73 \pm 64,79$ i 164,57 \pm 95,99 відповідно).

Макроекономічні індикатори (ВНД/дн, ЗВОЗ/дн, ДВОЗ/дн, ЗВОЗ у \% від ВВП) у порівню-

Порівняльна таблиця макроекономічних індикаторів ВНД/дн, ЗВОЗ у \% від ВВП, ЗВОЗ/дн, ДВОЗ/дн ЗЄ та пострадянських країн

\begin{tabular}{|c|c|c|c|c|c|c|}
\hline & \multicolumn{2}{|c|}{$\begin{array}{c}\text { Західна Європа } \\
(n=21)\end{array}$} & \multicolumn{2}{|c|}{$\begin{array}{l}\text { Пострадянські } \\
\text { країни }(\mathrm{n}=17)\end{array}$} & & \\
\hline & $\mathrm{M}$ & $\pm \sigma$ & $\mathrm{M}$ & $\pm \sigma$ & & \\
\hline ВНД/дн, \$ & 45203,33 & 18357,71 & 11130,59 & 5818,585 & 7,343 & $<0,001$ \\
\hline ВНД/дн (ПКС) & 38506,67 & 10956,17 & 17534,71 & 5516,810 & 7,177 & $<0,001$ \\
\hline ЗВОЗ (\% від ВВП) & 9,62 & 1,65 & 7,62 & 1,371 & 4,002 & $<0,001$ \\
\hline ЗВОЗ/дн, \$ & 4309,95 & 2018,21 & 818,41 & 483,515 & 6,956 & $<0,001$ \\
\hline ЗВОЗ/дн (ПКС) & 3733,57 & 1288,79 & 1337,18 & 493,289 & 7,234 & $<0,001$ \\
\hline ДВОЗ/дн, \$ & 3303,29 & 1733,18 & 587,59 & 386,898 & 6,319 & $<0,001$ \\
\hline ДВОЗ/дн (ПКС) & 2844,24 & 1164,89 & 940,53 & 410,417 & 6,410 & $<0,001$ \\
\hline
\end{tabular}

Порівняльна таблиця макроекономічних індикаторів ВНД/дн, ЗВОЗ у \% від ВВП, ЗВОЗ/дн, ДВОЗ/дн країн ЗЄ та країн ЦСЄ

\begin{tabular}{|l|c|c|c|c|c|c|}
\hline & \multicolumn{2}{|c|}{ ЗЄ $(\mathrm{n}=21)$} & \multicolumn{2}{|c|}{ ЦСЄ $(\mathrm{n}=14)$} & \multirow{2}{*}{$\mathrm{t}$} & \multirow{2}{*}{$\mathrm{P}$} \\
\cline { 1 - 6 } & $\mathrm{M}$ & $\pm \sigma$ & $\mathrm{M}$ & $\pm \sigma$ & & \\
\hline ВНД/дн, \$ & 45203,33 & 18357,71 & 12161,43 & 5769,94 & 6,495 & $<0,001$ \\
\hline ВНД/дн (ПКС) & 38506,67 & 10956,17 & 18257,14 & 5326,49 & 6,406 & $<0,001$ \\
\hline ЗВОЗ (\% від ВВП) & 9,62 & 1,65 & 7,80 & 1,39 & 3,396 & $<0,002$ \\
\hline ЗВОЗ/дн, \$ & 4309,95 & 2018,21 & 901,71 & 484,05 & 6,173 & $<0,001$ \\
\hline ЗВОЗ/дн, \$ (ПКС) & 3733,57 & 1288,79 & 1419,14 & 481,71 & 6,401 & $<0,001$ \\
\hline ДВОЗ/дн, \$ & 3303,29 & 1733,18 & 658,29 & 388,75 & 5,591 & $<0,001$ \\
\hline ДВОЗ/дн, \$ (ПКС) & 2844,24 & 1164,89 & 1016,79 & 405,67 & 5,623 & $<0,001$ \\
\hline
\end{tabular}

вищими ( $t=2,180 ; \mathrm{p}<0,05)$, ніж у $\mathrm{CHД} \mathrm{(M \pm \sigma =39,24 \pm 37,08).}$

Середні значення макроекономічних індикаторів (ВНД/дн, ЗВОЗ у \% від ВВП, ЗВОЗ/дн, ДВОЗ/дн), наведені у таблиці 6, хоча і були більшими у групі країн ЦСЄ, але не мали достовірних відмінностей від групи країн СНД.

Таким чином, країни цСЄ, на відміну від країн СНД, мали більш розвинуту інфраструктуру, пов'язану з ТГСК, та вищі PTA для аутологічних ТГСК. Не встановлено статистично значимих відмінностей між макроекономічними індикаторами (ВНД/дн, ЗВОЗ у \% від ВВП, ЗВОЗ/дн і ДВОЗ/дн) порівнюваних груп, а також загальними РТА та для алогенних ТГСК.

Порівняльний аналіз між країнами ЦСЄ та Східного Середземномор'я/Африки показав, що ЩТК у ЦСЄ (M $\pm \sigma=0,61 \pm 0,32)$ була вірогідно вищою $(t=3,514 ; p<0,003)$, ніж у Східному Середземномор'ї/ Африці (M $\pm \sigma=0,16 \pm 0,14)$. Загальний РТА у групі країн ЦС€ (M $\pm \sigma=242,30 \pm 154,04)$ був достовірно вищим $(t=2,685 ; \quad p<0,02), \quad$ ніж $y$ Східному Середземномор'ї/ Африці (M $\pm \sigma=81,46 \pm 40,06)$. РТА для алогенних ТГСК у ЦСЄ ( $\mathrm{M} \pm \sigma=77,73 \pm 64,79$ ) достовірно не відрізнялися $(t=1,454$; $\mathrm{p}=0,16)$ від країн Східного Середземномор'я/Африки (М $\pm \sigma=40,63 \pm 22,77)$. Для аутологічних ТГСК РТА у ЦСЄ $(\mathrm{M} \pm \sigma=164,57 \pm 95,99)$ були достовірно вищими ( $\mathrm{t}=3,317$; $\mathrm{p}<0,004)$, ніж у Східному Середземномор'ї/ Африці (М $\pm \sigma=40,83 \pm 24,60)$.

Як видно із таблиці 7, середні значення ВНД/дн, а також ЗВОЗ у \% від ВВП хоча і були вищими у групі країн ЦСЄ, але достовірно не відрізнялися від Східного Середземномор'я/ Африки. Але ЗВОЗ/дн та ДВОЗ/дн (у дол. США та за ПКС) були вірогідно вищими у групі країн ЦСЄ порівняно 3 країнами Східного Середземномор'я/Африки.

Таким чином, країни цСЄ, на відміну від країн Східного Середземномор'я/Африки, мали достовірно вищі подушові загальні і державні видатки на охорону здоров'я, більш розвинуту інфраструктуру, пов'язану з ТГСК, як наслідок достовірно вищі РТА (загальні та для аутологічних ТГСК). У 
порівнюваних групах не встановлено статистично значимих відмінностей між показниками ВНД/дн, ЗВОЗ у \% від ВВП та РТА для алогенних ТГСК.

Порівняльний аналіз між країнами-членами ЕВМТ, СНГ та Східного Середземномор'я/ Африки не виявив статистично значимих відмінностей за жодним 3 досліджуваних показників: РТА (загальним, для алогенних і аутологічних ТГСК), ЩТК, ВНД/дн, ЗВОЗ/дн, ДВОЗ/дн, ЗВОЗ у \% від ВВП.

\section{Висновки}

1. Регіональна трансплантаційна активність та інфраструктура, пов'язана 3 ТГСК, в Європі та Східному Середземномор'ї/Африці асоційована з рівнями економічного розвитку, загальними і державними видатками на охорону здоров'я країн-членів ЕВМТ відповідного регіону. РТА (загальні, для алогенних і аутологічних ТГСК) країн-членів ЕВМТ позитивно корелюють з показниками ЩТК, макроекономічними індикаторами (ВНД/дн, ЗВОЗ/ дн, ДВОЗ/дн), розрахованими у дол. США і за ПКС, а також ЗВОЗ у \% від ВВП.

2. Розвиток ТГСК та інфраструктури, пов'язаної з нею, у країнах-членах ЕВМТ Європи та Східного Середземномор'я/Африки має диспропорційний характер, обумовлений суттєвими відмінностями в їхніх рівнях економічного розвитку.

3. Трансплантаційна активність та інфраструктура, пов'язана з ТГСК, сконцентровані у країнах з високими доходами, згідно з класифікацією Світового банку, більшими загальними і державними видатками на охорону здоров'я, серед яких країнам Західної Європи належить провідне місце. Наступні місця у порядку убування доходів та асоційованих 3 ними РТА посідають країни Центральної і Східної Європи, СНД та Східного Середземномор'я/Африки. у країнах цих регіонів з низькими доходами не було виконано жодної ТГСК.

4. Низький рівень економічного розвитку України, яка згідно 3 класифікацією Світового банку належить до категорії країн 3 «доходом нижче середнього», $€$ причиною її значного відставання від провідних країн Європи і світу у галузі ТГСК. Дефіцит ресурсів заважає інвестувати у розвиток інфраструктури (центри ТГСК, реєстри/банки донорів, підготовку персоналу) та на проведення самих оперативних втручань.

Наша країна з метою розвитку ТГСК потребує розробки та впровадження інвестиційної стратегії, спрямованої на подолання кількісного і якісного відставання у цій галузі медицини. Разом з тим паралельного розвитку потребує вся інфраструктура, пов'язана з ТГСК: гематологічна та онкологічна служба, центри крови, Всеукраїнський реєстр донорів гемопоетичних стовбурових клітин (кісткового мозку) Міністерства охорони здоров'я України та інші.

Перехід на диференційоване фінансування залежно від ступеня складності та ресурсоємності ТГСК, а також вирішення низки питань нормативно-правового характеру дозволять оптимізувати роботу центрів ТГСК і впровадити у клінічну практику трансплантації від неродинних донорів, які нині неможливо виконати в Україні. Відмовившись від проведення цих ТГСК за кордоном, наша країна отримає значний економічний ефект.

Таблиця

ВНД/дн, ЗВОЗ у \% від ВВП, ЗВОЗ/дн, ДВОЗ/дн між групами країн цСЄ та СНД

\begin{tabular}{|l|c|c|c|c|c|c|}
\hline & \multicolumn{2}{|c|}{ ЦСЄ $(\mathrm{n}=14)$} & \multicolumn{2}{c|}{ СНД $(\mathrm{n}=3)$} & \multirow{2}{*}{$\mathrm{t}$} & $\mathrm{P}$ \\
\cline { 2 - 5 } & $\mathrm{M}$ & $\pm \sigma$ & $\mathrm{M}$ & $\pm \sigma$ & & \\
\hline ВНД/дн, \$ & 12161,43 & 5769,94 & 6320,00 & 3506,67 & 1,663 & $<0,12$ \\
\hline ВНД/дн (ПКС) & 18257,14 & 5326,49 & 14163,33 & 6193,87 & 1,181 & $<0,26$ \\
\hline ЗВОЗ (\% від ВВП) & 7,80 & 1,39 & 6,77 & 1,11 & 1,201 & $<0,25$ \\
\hline ЗВОЗ/дн, \$ & 901,71 & 484,05 & 429,67 & 268,40 & 1,609 & $<0,13$ \\
\hline ЗВОЗ/дн, \$ (ПКС) & 1419,14 & 481,71 & 954,67 & 414,59 & 1,542 & $<0,15$ \\
\hline ДВОЗ/дн, \$ & 658,29 & 388,75 & 257,67 & 130,13 & 1,725 & $<0,11$ \\
\hline ДВОЗ/дн, \$ (ПКС) & 1016,79 & 405,67 & 584,67 & 217,15 & 1,760 & $<0,10$ \\
\hline
\end{tabular}

Порівняльна таблиця макроекономічних індикаторів ВНД/дн, ЗВОЗ у \% від ВВП, ЗВОЗ/дн, ДВОЗ/дн країн ЦСЄ та Східного Середземномор'я/Африки

\begin{tabular}{|l|c|c|c|c|c|c|}
\hline \multirow{2}{*}{} & \multicolumn{2}{|c|}{ ЦСє $(\mathrm{n}=14)$} & \multicolumn{2}{|c|}{$\begin{array}{c}\text { Східне Середземно- } \\
\text { мор'я/Африка }(\mathrm{n}=7)\end{array}$} & \multirow{2}{*}{$\mathrm{t}$} & $\mathrm{p}$ \\
\cline { 1 - 6 } & $\mathrm{M}$ & $\pm \sigma$ & $\mathrm{M}$ & $\pm \sigma$ & & \\
\hline ВНД/ДН, \$ & 12161,43 & 5769,94 & 7204,29 & 5209,93 & 1,912 & $<0,07$ \\
\hline ВНД/ДН (ПКС) & 18257,14 & 5326,49 & 17398,57 & 11990,85 & 0,230 & $<0,82$ \\
\hline ЗВОЗ (\% ВІД ВВП) & 7,80 & 1,39 & 6,77 & 1,82 & 1,447 & $<0,16$ \\
\hline ЗВОЗ/ДН, \$ & 901,71 & 484,05 & 452,00 & 183,18 & 2,350 & $<0,03$ \\
\hline ЗВОЗ/ДН, \$ (ПКС) & 1419,14 & 481,71 & 996,29 & 325,11 & 2,084 & $<0,05$ \\
\hline ДВОЗ/ДН, \$ & 658,29 & 388,75 & 238,14 & 102,73 & 2,778 & $<0,02$ \\
\hline ДВОЗ/ДН, \$ (ПКС) & 1016,79 & 405,67 & 536,43 & 228,15 & 2,889 & $<0,01$ \\
\hline
\end{tabular}


4. Stranges E., Russo C.A., Friedman B. Procedures with the most rapidly increasing hospital costs, 2004-2007. HCUP statistical brief №82. December 2009. Agency for Healthcare Research and Quality, Rockville, MD, USA. Available from: http://www. hcup-us.ahrqgov/reports/statbriefs/sb82.pdf

5.Gratwohl A., Baldomero H., Gratwohl M. et al. Quantitative and qualitative differences in use and trends of hematopoietic stem cell transplantation: a Global Observational Study // Haematologica. 2013. 27 p.

6. Passweg J.R., Baldomero H., Gratwohl A. et al. The EBMT activity survey: 19902010. Bone Marrow

Transplantation. 2012. V. 47. P. 906-923.

7. http://www. worldbank.org

8. http://www. who.org .

REFERENCES

1. Khera N., Zeliadt S. B., Lee S. $\mathrm{J}$. Economics of hematopoietic cell transplantation // Blood. 2012. V. 120. № 8. P. 1545-1551.

2. Gratwohl A., Baldomero H. Aljurf M. et al. Hematopoietic stem cell transplantation: A Global Perspective // JAMA. 2010. V. 303. № 16. P. 1617-1624.

3. Niederwieser D., Baldomero H., Szer J. et all. Hematopoietic stem cell transplantation activity worldwide in 2012 and a SWOT analysis of the Worldwide Network for Blood and Marrow Transplantation Group including the global survey // Bone Marrow Transplant. 2016. V. 51. № 6. P. 778-785.

4. Stranges E., Russo C.A., Friedman B. Procedures with the most rapidly increasing hospital costs, 2004-2007. HCUP statistical brief №82. December 2009. Agency for Healthcare Research and Quality, Rockville,MD, USA. Available from: http://www. hcup-us.ahrqgov/reports/statbriefs/sb82.pdf

5.Gratwohl A., Baldomero H., Gratwohl M. et al. Quantitative and qualitative differences in use and trends of hematopoietic stem cell transplantation: a Global Observational Study // Haematologica. 2013. 27 p.

6. Passweg J.R., Baldomero H., Gratwohl A. et al. The EBMT activity survey: 1990-2010. Bone Marrow Transplantation. 2012. V. 47. P. 906-923.

7. http://www.worldbank.org .

8. http://www. who.org

надійшла до редакції 24.06.2017

IN ALIEN LABYRINTHS OF CIVILIZATION

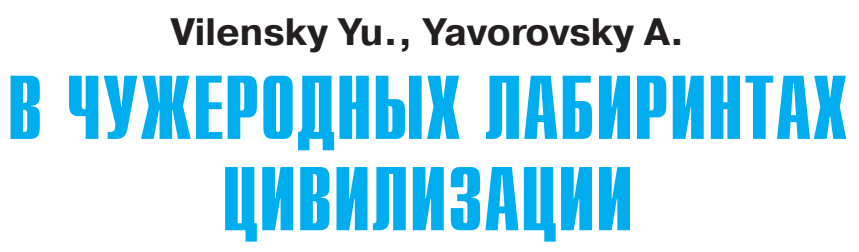

\section{Размышления о книге Д.Д. Зербино «Экологическая патология: проблема превентивной медицины. Концепция первичной профилактики". Киев, ООО “Медикс групп”, 2016.}

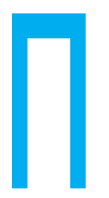

ромедление - всегда ошибка. В этом смысле ученых-патологов, постигающих в силу своей профессии, почему и как завершается жизнь, можно отнести и к социальным диагностам. Символично, что первым мыслителем в этом концептуальном круге, отметившим, что «история искусственных эпидемий является историей нарушений человеческой культуры», как подчеркивается в монографии, был Рудольф Вирхов. К данной плеяде аналитических умов принадлежит и видный украинский ученый, член-корреспондент НАН Украины, академик НАМН Украины, заведующий кафедрой патологической анатомии ЛНМУ имени Даниила Галицкого (1966-1993), создатель Института клинической патологии во Львове Дмитрий Деонисович Зербино.

Показательно, что проблематике общественного здоровья уделял большое внимание и создатель первой кафедры общей патологии в Университете святого Владимира, профессор Никанор Адамович Хржонщевский.

Как возникли новые экологичиские диспозиции? Сопоставляя патологические признаки, характерные для западного региона в течение первой половины XX столетия, чему способствовали и сохранившиеся данные прозектур, Д.Д. Зербино зафиксировал более сорока лет назад возникновение новых разновидностей сосудистой патологии, причем преимущественно уже в молодом возрасте - васкулитов, ангиопатий, артериосклероза, как бы обгоняющих классический возрастной атеросклероз. Ученый обратил внимание: страдали лица профессий, связанных с ксенобиотическими загрязнениями и загрузками. Это - паяльщики, сварщики, маляры, литейщики, лица, контактирующие с пестицидами или работающие на предприятиях с использованием химических ингредиентов либо тяжелых металлов. В размышлениях об этих совпадениях и возникла его концепция о роли экологической патологии в пространстве предболезней и болезней и ключевой роли, которая в связи с этим должна принадлежать превентивной медицине, а в глобальном смысле гигиеническим наукам в реальном действии. Концепция академика Д.Д. Зербино вполне созвучна и хорошо корреспондируется с современной тенденцией реформирования отечественного здравоохранения в части создания системы общественного здравоохранения Publick Health.

Монография состоит из 43 весьма лаконичных, но насыщенных документальными таблицами разделов, которые, как пишет в предисловии Ольга Барна (доктор медицинских наук, лидер «Всеукраинской ассоциации превентивной и антивозрастной медицины»), начали печататься с 2010 года в журнале «Мистецтво лікування». Этот цикл публикаций способствовал развитию гипотезы, а далее - концепции Д.Д. Зербино, что именно ксенобиотики и вызывают патогенез и симптоматику экологической патологии, наиболее ярко проявляющейся в кризисном 